\title{
Protective role of adenovirus vector-mediated interleukin-10 gene therapy on endogenous islet $\beta$-cells in recent-onset type 1 diabetes in NOD mice
}

\author{
CHENG LI ${ }^{1,2}$, LIJUAN ZHANG ${ }^{1}$, YANYAN CHEN $^{3}$, XIAOJIE LIN ${ }^{1}$ and TANG LI ${ }^{1}$ \\ ${ }^{1}$ Department of Pediatrics, Affiliated Hospital of Qingdao University, Qingdao, Shandong 266001; \\ ${ }^{2}$ Medical College, Qingdao University, Qingdao, Shandong 266071; ${ }^{3}$ Department of Pediatrics, \\ People's Hospital of Rizhao, Rizhao, Shandong 276800, P.R. China
}

Received December 18, 2014; Accepted February 11, 2016

DOI: 10.3892/etm.2016.3169

\begin{abstract}
The aim of the present study was to provide an animal experimental basis for the protective effect of the adenoviral vector-mediated interleukin-10 (Ad-mIL-10) gene on islet $\beta$-cells during the early stages of type 1 diabetes (T1D) in non-obese diabetic (NOD) mice. A total of 24 female NOD mice at the onset of diabetes were allocated at random into three groups ( $n=8$ per group): Group 1, intraperitoneally injected with $0.1 \mathrm{ml}$ Ad-mIL-10; group 2, intraperitoneally injected with $0.1 \mathrm{ml}$ adenovirus vector; and group 3 , was a diabetic control. In addition to groups 1, 2 and 3, 8 age- and gender-matched NOD mice were intraperitoneally injected with $0.1 \mathrm{ml}$ PBS and assigned to group 4 as a normal control. All mice were examined weekly for body weight, urine glucose and blood glucose values prior to onset of diabetes, and at 1 , 2 and 3 weeks after that, and all mice were sacrificed 3 weeks after injection. Serum levels of interleukin (IL)-10, interferon (IFN)- $\gamma$, IL-4, insulin and C-peptide were evaluated, and in addition the degree of insulitis and the local expression of IL-10 gene in the pancreas were detected. The apoptosis rate of pancreatic $\beta$-cells was determined using a TUNEL assay. Compared with groups 2 and 3, IL-10 levels in the serum and pancreas were elevated in group 1 . Serum IFN- $\gamma$ levels were decreased while serum IL-4 levels and IFN- $\gamma / \mathrm{IL}-4$ ratio were significantly increased in group $1(\mathrm{P}<0.01)$. C-peptide and insulin levels were higher in group 1 compared with groups 2 and $3,(\mathrm{P}<0.01)$. Furthermore, compared with groups 2 and 3 , the degree of insulitis, islet $\beta$-cell apoptosis rate and blood glucose values did not change significantly $(\mathrm{P}>0.05)$.
\end{abstract}

Correspondence to: Mr. Tang Li and Mrs. Cheng Li, Department of Pediatrics, Affiliated Hospital of Qingdao University, 16 Jiangsu Road, Qingdao, Shandong 266001, P.R. China

E-mail: drlitang@hotmail.com

E-mail: chainn0602@126.com

Key words: type 1 diabetes, interleukin 10, immunotherapy, non-obese diabetic mice
The administration of the Ad-mIL-10 gene induced limited immune regulatory and protective effects on islet $\beta$-cell function in NOD mice with early T1D, while no significant reduction in insulitis, islet $\beta$-cell apoptosis rate and blood glucose was observed.

\section{Introduction}

Type 1 diabetes (T1D) is caused by the absence of insulin, resulting in a class of persistently elevated blood sugar diabetes (1). Immune dysfunction-induced pancreatic $\beta$-cell apoptosis is crucially involved in the pathogenesis of this disease (2). A variety of immune cells and cytokines are involved in this process (3). Among them, T helper (Th) cell subpopulations imbalance has attracted significant attention (4). T cells are divided into helper, regulatory and cytotoxic T cells, according to their surface markers and function. Th consists of Th1 and Th 2 cell subsets based on different secretory cytokine (5). Th1 cells secrete factors including interleukin (IL)-1, IL-2, IL-12, interferon (IFN)- $\gamma$ and tumor necrosis factor (TNF)- $\alpha$ (5). The Th1 subset is involved in cell immune response and inflammatory-mediated apoptosis of islet $\beta$-cells (6). Some studies have discovered that the Th1 subset dominates in the body of T1D patients. After the intervention and down-regulation of a proportion of the Th1 subset, the T1D incidence is significantly decreased $(4,7)$. The Th2 subset is known to secrete IL-4, IL-10, IL-5, IL-6, IL-9 and IL-13, amongst other factors (5). Some studies have observed that T1D is controlled following intervention and the recovery of the Th2 proportion (8). Therefore, it can be suggested that Th2 serves a positive role in regulating immune homeostasis and in protecting the function of residual pancreatic beta cells. Th2 was a potential therapeutic strategy for the treatment of T1D (9).

IL-10 is an important Th2 cytokine. IL-10 can suppress the antigen presentation function by inhibiting the expression of MHC-II molecules on the surface of mononuclear macrophages. In addition, IL-10 serves an important role in immunosuppression and anti-apoptosis by suppressing the release of inflammatory factors of mononuclear macrophages (10-12). Numerous autoimmune diseases are associated 
with the decreased expression of IL-10 in vivo (13-14). A previous study demonstrated that the low expression of IL-10 in the pancreas mediates the occurrence of T1D (15). In addition, a previous study observed that there is a decreased expression of IL-10 in newly diagnosed children with T1D; as age increases, the level of IL-10 expression decreases (16). Based on the theory that low expression levels of IL-10 may promote the occurrence of T1D (16), attempts have been made to supplement exogenous IL-10 in order to treat T1D. However, as the half-life period of IL-10 is very short in vivo (17), it will significantly affect the efficacy of IL-10.

In a prior study, we successfully constructed the adenoviral vector-mediated interleukin-10 (Ad-mIL-10) (18). IL-10 was found to exert a protective effect in vitro on islet $\beta$-cells, and has been shown to reduce the occurrence of T1D in non-obese diabetic (NOD) mice (19). After that, we used STZ and $\mathrm{BALB} / \mathrm{c}$ mice to prepare the T1D model, and IL-10 was injected into the model rats. We found that IL-10 could not reverse the occurrence of T1D. The above results are related to the interference of STZ to the experiment. In the present study, the natural onset of T1D was identified in NOD mice, and the protective effect of Ad-mIL-10 in islet $\beta$-cells was evaluated.

\section{Materials and methods}

Animals. A total of 24 female NOD/Lt mice (specific-pathogen free; age, 7-9 weeks; weight, 19-21 g) were purchased from the Institute of Experimental Animals of the Chinese Academy of Medical Sciences (Beijing, China). T1D natural incidence rate was $>70 \%$ when these NOD mice were aged 25 weeks. The mice were housed in specific pathogen-free conditions under a 12-h dark/light cycle in ventilated filter cages with free access to food and water, at the Affiliated Hospital of the Medical College of Qingdao University (Qingdao, China). All mice were examined for polyphagia, polydipsia, polyuria, hair gloss and decreased activity. Body weight, urine glucose and blood glucose values were recorded weekly. Mice with glucosuria were tested for the blood glucose level, and those with a blood glucose level of $\geq 250 \mathrm{mg} / \mathrm{dl}$ (13.9 mmol/l) in two consecutive weeks were considered diabetic (20).

Equipment. Mouse IL-4 ELISA (cat. no. M4008); mouse IFN- $\gamma$ ELISA (cat. no. MIF00); mouse IL-10 ELISA (cat. no. M1008) (all purchased from R \& D Systems); mouse C-peptide ELISA (cat. no. 7651); mouse insulin ELISA (cat. no. M7647) (both purchased from Biotang, Inc., Waltham, MA,USA); carbon dioxide incubator (series II); microtome (Finesse325) (both purchased from Thermo Fisher Scientific, Inc., Waltham, MA, USA); clean bench (cat. no. SW2CJ22FD; Suzhou SuJie Purifying equipment Co., Ltd., Suzhou, China); microplate reader (Tecan Group, Ltd., Männedorf, Switzerland); constant temperature oscillator (cat. no. THZ-313; Shenzhen Tongyi Industry Company, Ltd., Shenzhen, China); hematoxylin and eosin staining kit (Beijing Solarbio Science \& Technology Co., Ltd., Beijing, China); In Situ Cell Death Detection kit (cat. no. 11684817910; Roche Diagnostics, Basel, Switzerland); VECTASTAIN Elite ABC kit (cat. no. PK6200; Vector Laboratories, Servion, Switzerland); Rapid Adeno Virus Infectious Titer (TCID50) kit (cat. no. K-AD0001; Benyuan Zhengyang Gene Technology Co., Ltd., Beijing China).
Reagents. Fetal bovine serum (FBS; Gibco, Thermo Fisher Scientific, Inc.); Dulbecco's modified Eagle's medium (DMEM; Hyclone, Logan, USA); hematoxylin and eosin; DAB (both purchased from Beijing Solarbio Science \& Technology Co., Ltd., Beijing, China); anti-IL-10 antibody (cat. no. ab189392; dilution, 1:2000; Abcam, Cambridge, UK); 1\% Triton-100 (Shaihong Rui Biological Technology Co., Ltd., Nanjing, China); $\mathrm{H}_{2} \mathrm{O}_{2}$-methanol solution ( $\mathrm{Yu}$ Bo Biological Technology Co., Ltd., Shanghai, China).

Human embryonic kidney (HEK) cell culture and adenovirus amplification. HEK 293 cells were donated by Professor Bing Luo of the Medical College of Qingdao University and cultured to amplify adenoviruses. Ad-mIL-10 was provided by Professor Zhihong Chen of the Department of Pediatrics of the Affiliated Hospital of the Medical College Qingdao University. Cells were cultured in DMEM supplemented with 10\% FBS for $24 \mathrm{~h}$ under standard conditions $\left(37^{\circ} \mathrm{C}, 5 \% \mathrm{CO}_{2}\right)$. HEK293 cells were cultured in 6 well plates, and $200 \mu \mathrm{l}$ recombinant adenovirus vectors containing mice IL-10 genes were added into each well and cultured for 48 hours at $37^{\circ} \mathrm{C}$. The GFP positive cells were counted using an inverted fluorescence microscope (IX55; Olympus Corporation, Tokyo, Japan) and the proportion was $>80 \%$. The virus liquid was centrifuged for $10 \mathrm{~min}$ at $1,500 \mathrm{x} \mathrm{g}$, and a recombinant adenovirus titer assay was performed according to the manufacturer's instructions. The recombinant adenovirus titer was $1 \times 10^{6} \mathrm{pfu} / \mathrm{ml}$ and the prepared virus liquid was stored at $-80^{\circ} \mathrm{C}$.

The study was performed in strict accordance with the Guide for the Care and Use of Laboratory Animals issued by the National Institutes of Health. The protocol was approved by the Committee for the Ethics of Animal Experiments of Affiliated Hospital of the Medical College Qingdao University. Every effort was made to minimize animal suffering. The use of the animals in the study was approved by the Qingdao University Institutional Animal Care and Use Committee.

Animal grouping and treatment protocol. Twenty-four female NOD mice aged 17-20 weeks and with a diagnosis of diabetes within 3 days were allocated at random into 3 groups: Group 1, at the onset stage of T1D, mice in group 1 were intraperitoneally injected with $0.1 \mathrm{ml}$ Ad-mIL-10; group 2 mice were intraperitoneally injected with $0.1 \mathrm{ml}$ adenovirus vector; and group 3 mice were a diabetic control. In addition, 8 age- and gender-matched nondiabetic NOD mice were intraperitoneally injected with $0.1 \mathrm{ml}$ phosphate-buffered saline (PBS) and assigned to group 4 as the normal control. Mice were anaesthetized with $10 \%$ hydrate aldehyde $(0.1 \mathrm{ml}$; Biological Technology Co., Ltd., Shanghai, China). Blood was then taken from the eyeball, and the mice were sacrificed by cervical dislocation. Blood samples were left to clot for $1 \mathrm{~h}$ at room temperature prior to centrifuging for $15 \mathrm{~min}$ at $1000 \mathrm{x} \mathrm{g}$. The serum was then removed and samples were stored at $-80^{\circ} \mathrm{C}$. To avoid repeated freeze and thaw, the pancreases were separated immediately, formalin-fixed, embedded in paraffin and sectioned (3-5 $\mu \mathrm{m})$ using a microtome. Specimens were then stained with hematoxylin and eosin (HE) in order to observe islet inflammatory infiltration microscopically (BX51T-72P01; Olympus Corporation), then immunohistochemically stained to detect the local expression 
of IL-10. The apoptosis rate of the pancreatic $\beta$-cells was determined by terminal deoxynucleotidyl transferase dUTP nick end labeling (TUNEL) assay.

Immunohistochemical analysis. The expression of IL-10 in the pancreatic specimens was examined using the immunohistochemical StreptAvidin-Biotin Complex (SABC) method. In a x400 magnification high-power field, 5 pancreatic islets were observed on each slice. Cells showing brownish yellow granules in the cytoplasm were considered to be positive for IL-10 expression. The percentage of positive cells and staining intensity were calculated and used to quantify the expression of IL-10. Specimens with $<1,1-10$, 11-50, 51-80 and $>80 \%$ positive cells were scored as $0,1,2$, 3 and 4, respectively. Specimens with staining intensity of light yellow, yellow and brown particles were scored as 1 , 2 and 3, respectively. The total immunohistochemical score of a specimen was calculated as the product of the score for the percentage of positive cells and the score for staining intensity, and was expressed as $(-),(+),(++)$ and $(+++)$ for scores of $0,1-4,5-8$ and 9-12, respectively.

Insulitis scoring. Pancreas specimens stained with $\mathrm{HE}$ were examined under a light microscope (IX55; Olympus Corporation). Islet pathology of inflammatory infiltration was assessed microscopically in a double-blind manner by professional pathologists in 5 consecutive fields at $\mathrm{x} 400$ magnification. The results were graded based on the following scale (21): 0 , No insulitis; 1 , insulitis affecting $<25 \%$ of the islet; 2 , insulitis affecting $25-75 \%$ of the islet; and 3 , insulitis affecting $>75 \%$ of the islet. The number of the islets at each grade was counted and statistically analyzed.

Enzyme-linked immunosorbent assays (ELISAs) for determination of serum IL-10, IL-4, IFN- $\gamma$, C-peptide and insulin levels. Serum C-peptide, IL-10, IL-4 and IFN- $\gamma$ levels were measured using ELISA kits according to the manufacturer's instructions. Briefly, blood samples were left to clot for $1 \mathrm{~h}$ at room temperature prior to centrifugation for $15 \mathrm{~min}$ at $1,000 \mathrm{x} \mathrm{g}$. The samples were divided and stored at $-80^{\circ} \mathrm{C}$. The absorbance value was determined using a microplate reader. The limit of detection for the assay was $1 \mathrm{pg} / \mathrm{ml}$, and withinand between-run precision values were $<15 \%$. To evaluate the Th cell subset status, the concentration ratio of IFN- $\gamma / \mathrm{IL}-4$ was calculated.

TUNEL assay. TUNEL was performed following the manufacturer's instructions. Briefly, samples were soaked twice for $5 \mathrm{~min}$ in xylene, $5 \mathrm{~min}$ in absolute ethanol, $5 \mathrm{~min}$ in $95 \%$ ethanol, $5 \mathrm{~min}$ in $85 \%$ ethanol, $5 \mathrm{~min}$ in $70 \%$ ethanol and 3 times for $3 \mathrm{~min}$ in PBS. $1 \%$ Triton-100 was added to the sample and incubated at room temperature for $15 \mathrm{~min}$ then washed by PBS 3 times. $3 \% \mathrm{H}_{2} \mathrm{O}_{2}$-methanol solution was added for $15 \mathrm{~min}$, followed by washing with by PBS 3 times. Then, $100 \mu \mathrm{l}$ converter-POD (Roche Diagnostics) was added to each sample for $30 \mathrm{~min}$ at $37^{\circ} \mathrm{C}$, followed by washing with PBS 3 times. Samples was observed under the microscope following staining with hematoxylin and eosin staining (BX51T-72P01; Olympus Coroporation). Apoptotic cells (brown color) were visualized using a microscope at $\mathrm{x} 400$ magnification. The number of positive cells in every 100 islet cells was calculated as the islet cell apoptosis rate.

Statistical analysis. Data were analyzed for normality and homogeneity of variance. For those showing normality and homogeneity of variance in multiple groups were compared using analysis of variance and Least Significant Difference test. The results that did not exhibit normality and heterogeneity of variance were analyzed using $\mathrm{Log} / \mathrm{Ln} / \mathrm{Sin} / \mathrm{Sqrt}$ conversion, followed by normality and homogeneity of variance. Results that continued not to exhibit normality and homogeneity of variance were further analyzed using Games-Howell and Kruskal-Wallis rank sum tests. Data used for severity grading were analyzed using the Kruskal-Wallis rank sum test. All statistical analyses were conducted using SPSS software, version 16.0 (SPSS, Inc., Chicago, IL, USA) and $\mathrm{P} \leq 0.05$ was considered to indicate a statistically significant difference.

\section{Results}

Blood glucose and body weight values. Compared with the normal control mice in group 4, the diabetic mice in group 3 drank more water and purged more urine. In addition, group 3 mice were restless and easily irritated. The glossiness of their body hair was reduced. The above phenomena were more apparent at 3 weeks following the onset of the disease in mice in group 3 . The body weight of the mice in all groups at the onset stage of the disease showed no significant difference $(\mathrm{P}>0.05)$. However, at 3 weeks following injection, mice in group 1 showed significantly reduced body weight compared with mice in groups 2,3 and $4(\mathrm{P}<0.05)$ (Table I).

Prior to treatment, the average random blood glucose of mice in group 1 was similar to groups 2 and 3 ( $\mathrm{P}>0.05)$. No significant difference was detected in average random blood glucose among groups 1, 2 and 3 ( $\mathrm{P}>0.05)$ following the injection (Table II).

Pancreatic expression of $I L-10$. The levels of IL-10 in pancreas were evaluated using immunohistochemical SABC method. As shown in Table III and Fig. 1, the expression levels of IL-10 in groups 1 and 4 were significantly increased compared with groups 2 and $3(\mathrm{P}<0.01)$. However, no significant difference was detected between mice in groups 1 and 4 (P>0.05) (Table III and Fig. 1).

Degree of insulitis in mice. The degree of insulitis was examined by microscopy following HE staining and graded based on the criteria described above. As shown in Table IV and Fig. 2, the degree of insulitis of mice in group 4 was graded as 0 or 1 , showing increased islets. The degree of insulitis of mice in group 1 was graded as 1 or 2 . In particular, insulitis grade of mice in groups 2 or 3 was 2 or 3 , showing smaller and fewer islets, obvious infiltration of inflammatory cells, and abnormal islet cell morphology. Statistical analysis indicated that the degree of infiltration was significantly higher in mice in groups 1, 2 and 3 compared with group 4 $(\mathrm{P}<0.0083)$; however, this difference was not significantly significant among groups 1,2 and 3 ( $\mathrm{P}>0.0083$ ). 
Table I. Comparison of body weight of mice in different groups $(\bar{x} \pm \mathrm{S}, \mathrm{g})$.

\begin{tabular}{|c|c|c|c|c|}
\hline \multirow[b]{2}{*}{ Group } & \multirow[b]{2}{*}{ At onset of T1D } & \multicolumn{3}{|c|}{ Body weight after the onset of T1D } \\
\hline & & One week & Two weeks & Three weeks \\
\hline 1 & $23.66 \pm 3.19$ & $24.70 \pm 2.27$ & $24.21 \pm 3.12$ & $23.00 \pm 1.67^{\mathrm{a}}$ \\
\hline 2 & $22.85 \pm 1.89$ & $23.88 \pm 1.75$ & $23.77 \pm 1.60$ & $23.95 \pm 1.38$ \\
\hline 3 & $23.27 \pm 2.09$ & $23.79 \pm 2.16$ & $24.14 \pm 1.76$ & $24.18 \pm 1.84$ \\
\hline 4 & $24.01 \pm 2.70$ & $24.05 \pm 2.99$ & $25.58 \pm 2.78$ & $25.94 \pm 2.64$ \\
\hline
\end{tabular}

${ }^{\mathrm{a}} \mathrm{P}<0.05$ vs. group 3 . T1D, type 1 diabetes.

Table II. Comparison of blood glucose of mice in different groups $(\bar{x} \pm \mathrm{S}, \mathrm{mmol} / \mathrm{l})$.

\begin{tabular}{|c|c|c|c|c|}
\hline \multirow[b]{2}{*}{ Group } & \multirow[b]{2}{*}{ At onset of T1D } & \multicolumn{3}{|c|}{ Blood glucose after the onset of T1D } \\
\hline & & One week & Two weeks & Three weeks \\
\hline 1 & $20.88 \pm 3.48^{\mathrm{a}}$ & $20.02 \pm 8.64^{\mathrm{a}}$ & $24.40 \pm 7.72^{\mathrm{a}}$ & $26.03 \pm 8.16^{\mathrm{a}}$ \\
\hline 2 & $20.38 \pm 5.29^{\mathrm{a}}$ & $21.5 \pm 4.03^{\mathrm{a}}$ & $23.83 \pm 5.32^{\mathrm{a}}$ & $26.14 \pm 5.15^{\mathrm{a}}$ \\
\hline 3 & $21.50 \pm 7.86^{\mathrm{a}}$ & $21.50 \pm 9.13^{\mathrm{a}}$ & $24.38 \pm 9.92^{\mathrm{a}}$ & $26.88 \pm 9.58^{a}$ \\
\hline 4 & $5.40 \pm 1.38$ & $6.16 \pm 0.28$ & $6.21 \pm 0.75$ & $6.28 \pm 1.17$ \\
\hline
\end{tabular}

${ }^{\text {aP }}<0.05$ vs. group 3 . T1D, type 1 diabetes.
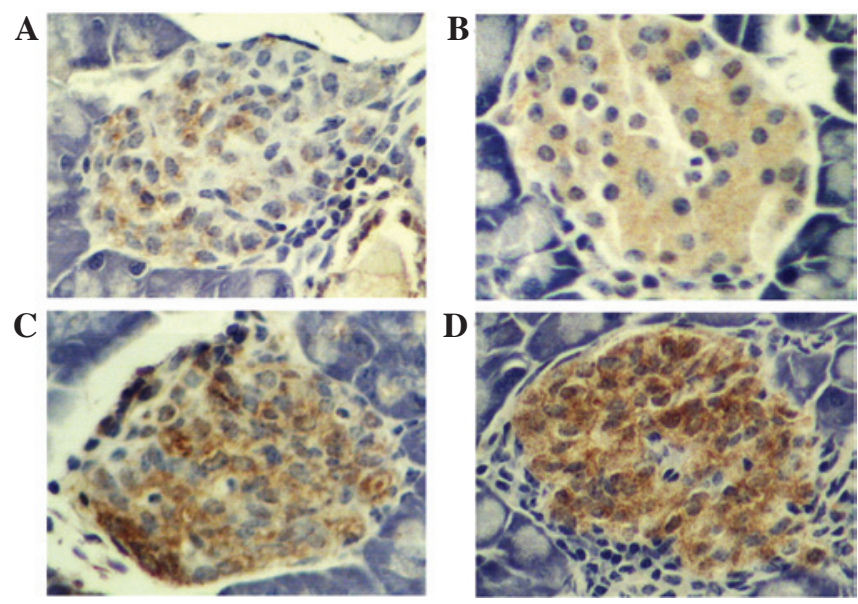

Figure 1. Interleukin-10 immunohistochemical staining level of pancreatic biopsy section under microscope (3,3-diaminobenzidine stain; magnification, $x 400)$. Parts (A), (B), (C) and (D) represent grades (-), (+), (++) and (+++), respectively.

Determination of serum cytokine levels. As shown in Table V, the serum IFN- $\gamma$ levels of the mice in groups 2 and 3 were significantly elevated compared with groups 1 and $4(\mathrm{P}<0.01)$. By contrast, serum IL-4 levels in groups 2 and 3 were significantly reduced compared with groups 1 and $4(\mathrm{P}<0.01)$. In addition, compared with the group 4 mice, serum IFN- $\gamma$ levels of the mice in group 1 were increased, while serum IL-4 levels was decreased, while there was significant difference in these two groups $(\mathrm{P}<0.01)$. The serum IFN- $\gamma / \mathrm{IL}-4$ ratio of mice in groups 2 and 3 were significantly elevated compared with groups 1 and $4(\mathrm{P}<0.01)$. Furthermore, the serum IFN- $\gamma / \mathrm{IL}-4$
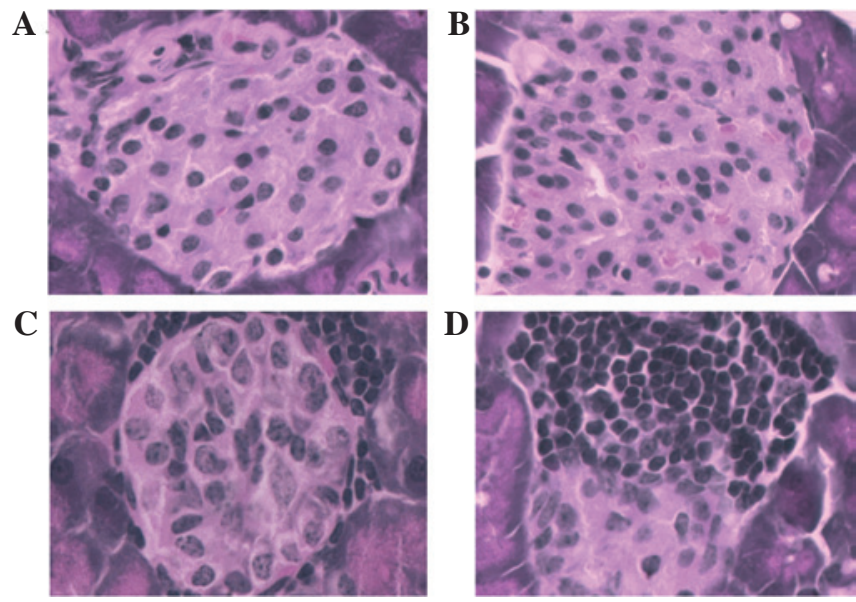

Figure 2. Degree of inflammation infiltration of islet cells in hematoxylin and eosin stained section under microscope (magnification, $\mathrm{x} 400$ ). Parts (A), (B), (C) and (D) represent grades 0, 1,2 and 3 of inflammation infiltration of islet cells, respectively.

ratio of the mice in group 1 was significantly increased compared group $4(\mathrm{P}<0.01)$.

Serum IL-10 levels in groups 1 and 4 were significantly higher compared with groups 2 and $3(\mathrm{P}<0.01)$, while serum IL-10 levels in group 1 were significantly reduced compared with group $4(\mathrm{P}<0.01)$.

As shown in Table VI, serum C-peptide and insulin levels of mice in group 4 were significantly higher compared with groups 1,2 and $3(\mathrm{P}<0.01)$. Similarly, serum C-peptide levels of mice in group 1 were significantly higher than that of mice in groups 2 and $3(\mathrm{P}<0.01)$. Serum insulin levels of mice in 
Table III. Immunostaining score of IL-10 of mice in different groups $(\bar{x} \pm S)(n=8$ cases per group).

\begin{tabular}{lc}
\hline Group & IL-10 \\
\hline 1 & $5.25 \pm 1.04^{\mathrm{a}, \mathrm{b}}$ \\
2 & $2.50 \pm 0.93^{\mathrm{c}}$ \\
3 & $2.25 \pm 1.16^{\mathrm{c}}$ \\
4 & $4.75 \pm 1.04$ \\
\hline
\end{tabular}

${ }^{\mathrm{a}} \mathrm{P}<0.0083$ vs. group 3 ; ${ }^{\mathrm{b}} \mathrm{P}<0.0083$ vs. group $2,{ }^{\mathrm{c}} \mathrm{P}<0.0083$ vs. group 4 . IL-10, interleukin-10.

Table IV. Number of islets in non-obese diabetic mice in each group for each grade pancreatitis.

\begin{tabular}{lrrrr}
\hline & \multicolumn{4}{c}{ Grade } \\
\cline { 2 - 5 } Group & 0 & 1 & 2 & 3 \\
\hline 1 & 3 & 13 & 14 & 10 \\
2 & 2 & 10 & 11 & 17 \\
3 & 1 & 9 & 12 & 18 \\
4 & 8 & 28 & 2 & 2 \\
\hline
\end{tabular}

group 1 was significantly higher than that of mice in groups 2 and $3(\mathrm{P}<0.01)$.

Effect of Ad-mIL-10 on pancreatic islet cell apoptosis. Pancreatic islet cell apoptosis was assessed using the TUNEL assay. As shown in Figs. 3 and 4, the apoptosis Urate of $\beta$-cells in group 4 was significantly reduced compared with groups 1 , 2 and $3(\mathrm{P}<0.01)$. However, there was no difference in the number of apoptotic cells (brown color) between groups 1 and 3 ( $\mathrm{P}>0.05)$. In addition, no significant difference in the apoptosis rate was observed between groups 2 and 3 ( $\mathrm{P}>0.05)$.

\section{Discussion}

Type 1 diabetes (T1D) is an immune-mediated disease resulting from inflammatory cell and cytokine-mediated destruction of pancreatic insulin-producing $\beta$-cells $(1,2)$. Currently, immunotherapy for T1D is focused on antigen-specific interventions, antibody-dependent interventions and cytokines (22). However, in general these methods fail to pass clinical trial stages II and III (23-26). This failure may be the result of a range of factors, including: i) Various islet autoantigens, immune disorders and a complex underlying mechanism; ii) effectively tolerated doses below the human therapeutic dose of drugs, and drugs producing significant adverse effects; iii) severe inflammatory infiltration of islets and damage to the majority of islet $\beta$-cells (27). It is difficult for clinicians to identify and treat diabetes early; and iv) animal experimental models cannot completely simulate the human pathogenesis of T1D, while other factors, such as genetic background and sensitivity to drugs, may also limit the application of immunotherapy in T1D.
Table V. Comparison of levels of serum IFN- $\gamma$, IL-4 and IFN- $\gamma / \mathrm{IL}-4(\bar{x} \pm \mathrm{S})$.

\begin{tabular}{lllc}
\hline Group & IFN- $\gamma(\mathrm{pg} / \mathrm{ml})$ & IL-4 $(\mathrm{pg} / \mathrm{ml})$ & IFN- $\gamma / \mathrm{IL}-4$ \\
\hline 1 & $298.66 \pm 18.16^{\mathrm{a}, \mathrm{b}, \mathrm{c}}$ & $45.58 \pm 1.70^{\mathrm{a}, \mathrm{b}, \mathrm{c}}$ & $6.55 \pm 0.39^{\mathrm{a}, \mathrm{b}, \mathrm{c}}$ \\
2 & $472.76 \pm 16.66^{\mathrm{a}}$ & $33.95 \pm 3.22^{\mathrm{a}}$ & $14.05 \pm 1.63^{\mathrm{a}}$ \\
3 & $479.76 \pm 24.73^{\mathrm{a}}$ & $32.57 \pm 4.32^{\mathrm{a}}$ & $15.01 \pm 2.56^{\mathrm{a}}$ \\
4 & $227.29 \pm 28.23$ & $79.12 \pm 5.18$ & $2.88 \pm 0.42$ \\
\hline
\end{tabular}

${ }^{\mathrm{a}} \mathrm{P}<0.01$ vs. group 4 ; ${ }^{\mathrm{b}} \mathrm{P}<0.01$ vs. group 3 ; ${ }^{\mathrm{c}} \mathrm{P}<0.01$ vs. group 2 . IFN $-\gamma$, interferon- $\gamma ;$ IL-4, interleukin-4.

Table VI. Comparison of levels of serum IL-10, C-peptide and insulin $(\bar{x} \pm \mathrm{S})$.

\begin{tabular}{llcl}
\hline Group & IL-10 $(\mathrm{pg} / \mathrm{ml})$ & C-peptide $(\mathrm{ng} / \mathrm{ml})$ & Insulin $(\mathrm{ng} / \mathrm{ml})$ \\
\hline 1 & $184.24 \pm 10.64^{\mathrm{a}, \mathrm{b}, \mathrm{c}}$ & $4.41 \pm 0.37^{\mathrm{a}, \mathrm{b}, \mathrm{c}}$ & $3.64 \pm 0.38^{\mathrm{a}, \mathrm{b}, \mathrm{c}}$ \\
2 & $127.33 \pm 7.31^{\mathrm{a}}$ & $3.40 \pm 0.19^{\mathrm{a}}$ & $2.91 \pm 0.52^{\mathrm{a}}$ \\
3 & $124.95 \pm 9.71^{\mathrm{a}}$ & $3.24 \pm 0.30^{\mathrm{a}}$ & $2.53 \pm 0.67^{\mathrm{a}}$ \\
4 & $264.65 \pm 30.02$ & $6.94 \pm 0.48$ & $6.53 \pm 0.51$ \\
\hline
\end{tabular}

${ }^{\mathrm{a}} \mathrm{P}<0.01$ vs. group 4 ; ${ }^{\mathrm{b}} \mathrm{P}<0.01$ vs. group 3 ; ${ }^{\mathrm{c}} \mathrm{P}<0.01$ vs. group 2 . IL-10, interleukin-10.
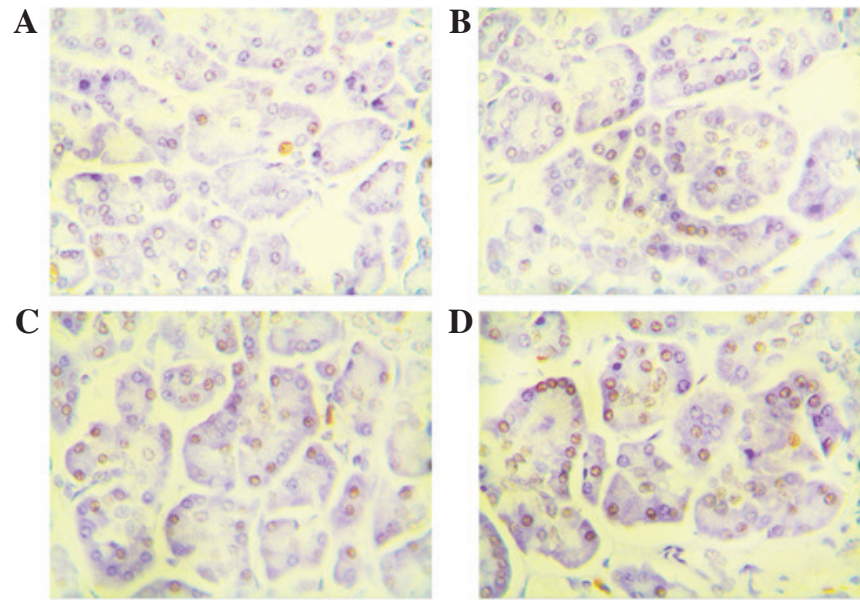

Figure 3. Apoptosis of islet of non-obese diabetic mice in the different groups with TUNEL staining (magnification, $x 400$ ). (A) Pancreata of mice in normal control group showed very few apoptotic nuclei. (B) Pancreata of mice in the Ad-mIL-10 group showed few apoptotic nuclei. (C) Pancreata of mice in Ad-ADV group stained widely for apoptotic nuclei by TUNEL. (D) Pancreata of mice in diabetic control group showed a large amount of apoptotic nuclei.

IL-10 is secreted primarily by Th2 cells, and exerts the following effects a range of effects. IL-10 markedly inhibits a broad spectrum of activated macrophage/monocyte functions, including monokine synthesis, production and expression of major histocompatibility complex-II and co-stimulatory molecules such as IL-12 and CD80/CD86 (28). IL-10 is able to reduce their role in antigen presentation (10). IL-10 can promote the expression of macrophage scavenger receptor, and enhanced phagocytic activity of macrophages (29). IL-10 may 


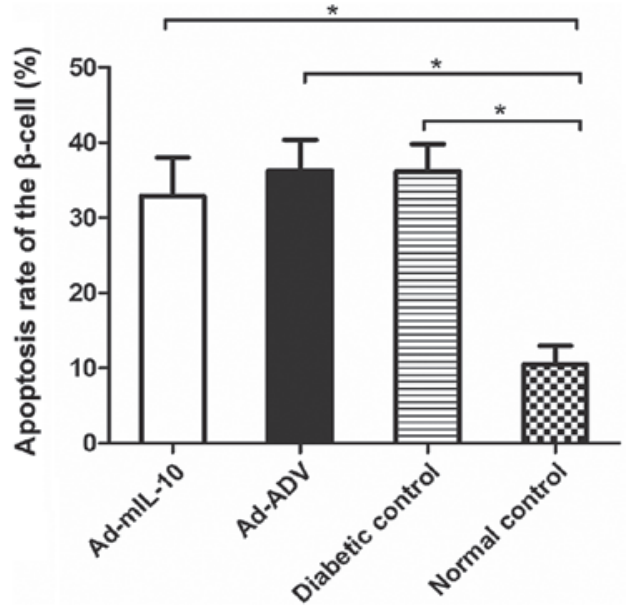

Figure 4. Apoptosis rate of $\beta$-cells in groups 4 was significantly lower compared with groups 1,2 and $3(\mathrm{P}<0.01)$. There was no difference in the number of apoptosis cells (brown color) between groups 1 and 3 ( $P>0.05$ ). In addition, no significant difference in the apoptosis rate was observed between groups 2 and $3\left({ }^{*} \mathrm{P}>0.05\right)$.

inhibit the activation of inflammatory cytokines (such as IL-1, IL-12 and TNF- $\alpha$ ) and chemokines (MCP family) secreted by antigen-presenting cells $(30,31)$. IL-10 can promote the expression of prostaglandin E2, as well as the differentiation and maturation of dendritic cells (32). IL-10 can inhibit the function of antigen-presenting cells, and thus indirectly inhibit the function of T-cells (33,34). In addition, IL-10 may be directly activated by the inhibitory signal transduction pathway in T cells. IL-10 may reduce Fas-mediated apoptosis by restricting caspase-3 activity through the upregulation of FLIP and downregulation of caspase-8 activity $(11,12)$.

The above functions constitute the key components of the anti-inflammatory and immunosuppressive effects of IL-10. As a result of these immunosuppressive abilities, IL-10 has been considered to be an effective agent for treating autoimmune diseases, such as T1D. As the half-life of exogenous IL-10 is short, the administration must be repeated, limiting the clinical application of IL-10. Viral vectors are attractive gene transfer vehicles, as they often mediate highly efficient gene transfer and stably express genes (35). Adenovirus vectors were employed in the present study as they have been shown to transduce pancreatic islet cells efficiently, with $>70 \%$ of human pancreatic endocrine cells and rodent islets being transduced ex vivo $(36,37)$. Pancreatic $\beta$-cell and adenovirus receptors are present on the surface, carrying the gene of an acceptable adenovirus vector, so that the IL-10 gene can be successfully introduced into pancreatic $\beta$-cells (19). The IL-10 adenovirus vector does not affect the normal function of cells after following its introduction into islet $\beta$ cell lines in vitro (19). Furthermore, the cells maintain insulin secretion function in response to the stimulation of a high concentration of sugar after transduction (19). The present study uses adenovirus infectious droplet kits to measure the degree of recombinant adenovirus drops and the result accords with the standard of transfection. In the current study, Ad-mIL-10 genes were successfully introduced into mice in vivo. Their level was marked high in pancreatic cells and serum, and maintained an elevated local drug concentration in a longer duration (38).
NOD mice with insulitis gradually exhibit polyuria, polydipsia, weight loss, irritability and loss in hair gloss (39). In the present study, these symptoms were particularly evident in group 3 mice. At 2 weeks after the onset of T1D, there was no significant difference in body weight among the groups. However, after injecting the Ad-mIL-10 in order to induce the expression of IL-10, body weight showed a downward trend, and was significantly reduced compared with group 4 . We speculated that Ad-mIL-10 may not be able to effectively control this weight loss trend in mice, and the drug itself may have caused this effect. Detection of blood glucose levels showed that mice treated with IL-10 had similar blood glucose levels to groups 2 and 3; however, these differences were not statistically significant. Thus, the present results indicated that IL-10 gene intervention could not effectively control the blood glucose level of NOD Mice and adenoviral vectors had no effect on blood glucose levels in mice. T1D pathogenesis in mice is similar to that in humans, including obvious islet inflammation and infiltration of inflammatory cells, such as dendritic cells, macrophages, $\mathrm{CD} 8^{+} \mathrm{T}$ cells, $\mathrm{CD} 4^{+} \mathrm{T}$ cells and $\mathrm{B}$ cells. The degree of islet inflammation of the mice in group 1 was mildly reduced, whereas there was no significant difference among mice in groups 1,2 and 3 . Therefore, we concluded that group 1 could not alleviate islet inflammation. The apoptosis rate of pancreatic $\beta$-cells was determined by TUNEL assay. The apoptosis rate in the genetic intervention group was slightly reduced. There was no significantly difference among mice in groups 1, 2 and 3. Therefore, the Ad-mIL-10 gene intervention could not reduce the islet $\beta$-cell apoptosis rate. The cause of the above results may be explained by the following: i) Due to the complexity of the pathogenesis of T1D, single immune agents can not achieve the desired effect; ii) injecting $0.1 \mathrm{ml}$ Ad-mIL-10 can not effectively control mice blood glucose level and alleviate insulitis; and iii) the residual quantity of islet $\beta$-cells may be associated with this result.

The immune system is a complex vast network of coordination between immune cells and immune molecules (40). Th1/Th2 lymphocyte subsets imbalance is key to the pathogenesis of T1D (4). Th1 cells secrete a variety of inflammatory cytokines, including IL-1, IFN- $\gamma$ and TNF- $\alpha$, and serve a crucial function in the destruction of islet $\beta$-cells (6). The role of IFN- $\gamma$ is vital, as IFN- $\gamma$ mediates apoptosis in pancreatic $\beta$-cells in the following ways: i) Directly terminating islet $\beta$-cells (41); ii) via the death caspase-3 receptor pathway and mitochondrial caspase- 9 , caspase-7 ways to accelerate apoptosis of islet $\beta$-cell; iii) IFN- $\gamma$ may induce macrophages and lymphocytes to produce more autoantigen-specific $\mathrm{T}$ cells into the islet (42), and increase the sensitivity of pancreatic $\beta$-cells to the damaging effects of $\mathrm{CD} 8^{+} \mathrm{T}$ cells, accelerating islet $\beta$ cell apoptosis (43). Th 2 cells are able to secrete a variety of cytokines. IL-4 also plays an important role, as it can inhibit the chemotaxis of inflammatory cells, promote the proliferation of Th2 cells and suppress immune response cells (44-46). Previous studies have found that serum IL-4 levels in NOD mice were significant reduced compared with normal (47), indicating that the low concentration of IL-4 could not inhibit the transformation of Th2 cells to Th1 cells. In addition, low concentration of IL-4 may also aggravate Th1/Th2 imbalance, and increase the Th1 cell secretion of IL-1, IFN- $\gamma$ and TNF- $\alpha$, thus aggravating islet $\beta$-cell damage (48). Compared 
with group 3 mice, mice treated with Ad-mIL-10 had significantly reduced IFN- $\gamma$ levels and enhanced IL-10 levels $(\mathrm{P}<0.01)$, suggesting that IL-10 produced better intervention outcomes. However, there was no difference between the mice treated with adenovirus vector and the diabetic control mice, suggesting that adenovirus vector had no effect on the experimental results.

Compared with mice in the control group, diabetic mice had significantly elevated IFN- $\gamma$ levels and decreased IL-4 levels $(\mathrm{P}<0.01)$, supporting the hypothesis of Th1/Th2 cell subsets imbalance and confirming that gene intervention with IL-10 was involved in rebalancing Th1/Th2 subsets, but could not completely reverse the imbalance.

$\mathrm{C}$-peptide is a by-product of proinsulin generate to insulin which secretion level directly reflects the functions of pancreatic $\beta$-cells (49). As a crucial bioactive ingredient, C-peptide has hormone-like effects on organs (50). In kidney cells, C-peptide can improve glomerular filtration, improve kidney function, alleviate glomerular mesangial cell proliferation, as well as reduce proteinuria $(51,52)$. In the nervous system, C-peptide can improve the blood supply of nerve cells and reduce neuronal apoptosis $(53,54)$. Since C-peptide can further prevent vascular endothelial damage, delay complications of cardiovascular disease (55), maintaining high levels of C-peptide may be crucial to patients. In the present study, C-peptide level of mice in the Ad-mIL-10 intervention group (group 1) was higher than that of mice in diabetic group (group 3), suggesting that Ad-mIL-10 could partly protect remaining pancreatic $\beta$-cell function whilst indirectly promoting insulin secretion. Furthermore, the insulin level of mice in group 1 was also higher than that of mice in group 3, suggesting that Ad-mIL-10 could promote the secretion of insulin by remaining pancreatic $\beta$-cells.

In summary, the present results show that Ad-mIL-10 intervention enhanced the expression of IL-10 in the pancreas and serum. In addition, the intervention increased the expression of protective Th2-type cytokines (IL-4) while reducing the level of destructive Th1-type cytokines (IFN- $\gamma$ ) in pancreatic $\beta$-cells, and increased serum C-peptide and insulin levels. However, the Ad-mIL-10 intervention could not improve blood glucose, reduce the islet $\beta$-cell apoptosis rate nor completely prevent insulitis. Therefore, single gene therapy may not be satisfactory for the treatment of the treatment of T1D, and a 'cocktail therapy' of combined genetic intervention may warrant further investigation.

\section{Acknowledgements}

This study was supported by the National Natural Science Foundation of China (grant no. 1170762) and Shandong Province Natural Science Foundation (grant no. Y2008C50).

\section{References}

1. Poradzka A, Wroński J, Jasik M, Karnafel W and Fiedor P: Insulin replacement therapy in patients with type 1 diabetes by isolated pancreatic islet transplantation. Acta Pol Pharm 70: 943-950, 2013.

2. Cnop M, Welsh N, Jonas JC, Jörns A, Lenzen S and Eizirik DL: Mechanisms of pancreatic beta-cell death in type 1 and type 2 diabetes: Many differences, few similarities. Diabetes 54 (Suppl 2): S97-S107, 2005.
3. Frostegård J: Immune mechanisms in atherosclerosis, especially in diabetes type 2. Front Endocrinol (Lausanne) 4: 162, 2013.

4. Sia C: Imbalance in Th cell polarization and its relevance in type 1 diabetes mellitus. Rev Diabet Stud 2: 182-186, 2005.

5. Mosmann TR and Sad S: The expanding universe of T-cell subsets: Th1, Th2 and more. Immunol Today 17: 138-146, 1996.

6. Rabinovitch A, Suarez-Pinzon W, El-Sheikh A, Sorensen O and Power RF: Cytokine gene expression in pancreatic islet-infiltrating leukocytes of BB rats: Expression of Th1 cytokines correlates with beta-cell destructive insulitis and IDDM. Diabetes 45: 749-754, 1996.

7. Axelsson S, Hjorth M, Ludvigsson J and Casas R: Decreased GAD(65)-specific Th1/Tc1 phenotype in children with Type 1 diabetes treated with GAD-alum. Diabet Med 29: 1272-1278,2012.

8. Petrovsky N, Silva D and Schatz DA : Vaccine therapies for the prevention of type 1 diabetes mellitus. Paediatr Drugs 5: 575-582, 2003.

9. Marselli L, Dotta F, Piro S, Santangelo C, Masini M, Lupi R, Realacci M, del Guerra S, Mosca F, Boggi U, et al: Th2 cytokines have a partial, direct protective effect on the function and survival of isolated human islets exposed to combined proinflammatory and Th1 cytokines. J Clin Endocrinol Metab 86: 4974-4978, 2001.

10. de Waal Malefyt R, Haanen J, Spits H, Roncarolo MG, te Velde A, Figdor C, Johnson K, Kastelein R, Yssel H and de Vries JE: Interleukin 10 (IL-10) and viralIL-10 strongly reduce antigen-specific human $\mathrm{T}$ cell proliferation by diminishing the antigen-presenting capacity of monocytes via downregulation of class II major histocompatibility complex expression. J Exp Med 174: 915-924, 1991.

11. Bharhani MS, Borojevic R, Basak S, Ho E, Zhou P and Croitoru K: IL-10 protects mouse intestinal epithelial cells from Fas-induced apoptosis via modulating Fas expression and altering caspase- 8 and FLIP expression. Am J Physiol Gastrointest liver Physiol 291: G820-G829, 2006.

12. Xiao Z, Mohamood AS, Uddin S, Gutfreund R, Nakata C, Marshall A, Kimura H, Caturegli P, Womer KL, Huang Y, et al: Inhibition of Fas ligand in NOD mice unmasks a protective role for IL-10 against insulitis development. Am J Pathol 179: 725-732, 2011.

13. Lim S, Crawley E, Woo P and Barnes PJ: Haplotype associated with low interleukin-10 production in patients with severe asthma. Lancet 352: 113, 1998.

14. López P, Gutiérrez C and Suárez A: IL-10 and TNFalpha genotypes in SLE. J Biomed Biotechnol 2010: 838390, 2010.

15. Teros T, Hakala R, Ylinen L, Liukas A, Arvilommi P, Sainio-Pöllänen S, Veräjänkorva E, Pöllänen $\mathrm{P}$ and Simell $\mathrm{O}$ : Cytokine balance and lipid antigen presentation in the NOD mouse pancreas during development of insulitis. Pancreas 20: 191-196, 2000.

16. Kaas A, Pfleger C, Kharagjitsingh AV, Schloot NC, Hansen L, Buschard K, Koeleman BP, Roep BO, Mortensen HB and Alizadeh BZ; Hvidoere Study Group on Childhood Diabetes: Association between age, IL-10, IFN $\gamma$, stimulated C-peptide and disease progression in children with newly diagnosed Type 1 diabetes. Diabet Med 29: 734-741, 2012

17. Mattos A, de Jager-Krikken A, de Haan M, Beljaars L and Poelstra K: PEGylation of interleukin-10 improves the pharmacokinetic profile and enhances the antifibrotic effectivity in $\mathrm{CCl}_{4}$-induced fibrogenesis in mice. J Control Release 162: 84-91, 2012 .

18. Xu AJ, Chen ZH, Tian F, Yan LH and Li T: Effects of adenovirus mediated interleukin-10 gene transfer on apoptosis and insulin secretion function of beta cell. Zhonghua Yi Xue Za Zhi 90: 1711-1715, 2010 (In Chinese).

19. Xu AJ, Zhu W, Tian F, Yan LH and Li T: Recombinant adenoviral expression of IL-10 protects beta cell from impairment induced by pro-inflammatory cytokine. Mol Cell Biochem 344: 163-171, 2010.

20. Kanagawa O, Militech A and Vaupel BA: Regulation of diabetes development by regulatory $\mathrm{T}$ cells in pancreatic islet antigen-specific TCR transgenic nonobese diabetic mice. J Immunol 168: 6159-6164, 2002.

21. Casellas A, Salavert A, Agudo J, Ayuso E, Jimenez V, Moya M, Muñoz S, Franckhauser S and Bosch F: Expression of IGF-I in pancreatic islets prevents lymphocytic infiltration and protects mice from type 1 diabetes. Diabetes 55: 3246-3255, 2006.

22. Chen W, Xie A and Chan L: Mechanistic basis of immunotherapies for type 1 diabetes mellitus. Transl Res 161: 217-229, 2013. 
23. Ludvigsson J, Krisky D, Casas R, Battelino T, Castaño L, Greening J, Kordonouri O, Otonkoski T, Pozzilli P, Robert JJ, et al: GAD65 antigen therapy in recently diagnosed type 1 diabetes mellitus. N Engl J Med 366: 433-442, 2012.

24. Vehik K, Cuthbertson D, Ruhlig H, Schatz DA, Peakman M and Krischer JP; DPT-1 and TrialNet Study Groups: Long-term outcome of individuals treated with oral insulin: Diabetes prevention trial-type 1 (DPT-1) oral insulin trial. Diabetes Care 34: 1585-1590, 2011.

25. Walter M, Philotheou A, Bonnici F, Ziegler AG and Jimenez R; NBI-6024 Study Group: No effect of the altered peptide ligand NBI-6024 on beta-cell residual function and insulin needs in new-onset type 1 diabetes. Diabetes Care 32: 2036-2040, 2009.

26. Sherry N, Hagopian W, Ludvigsson J, Jain SM, Wahlen J, Ferry RJ Jr, Bode B, Aronoff S, Holland C, Carlin D, et al; Protégé Trial Investigators: Teplizumab for treatment of type 1 diabetes (Protégé study): 1-Year results from a randomised, placebo-controlled trial. Lancet 378: 487-497, 2011.

27. Ludvigsson J; Linköping Diabetes Immune Intervention study group: Immune intervention in children with type 1 diabetes Curr Diab Rep 10: 370-379, 2010.

28. Moore KW, de Waal Malefyt R, Coffman RL and O'Garra A Interleukin-10 and the interleukin-10 receptor. Annu Rev Immunol 19: 683-765, 2001.

29. Buchwald UK, Geerdes-Fenge HF, Vöckler J, Ziege S and Lode H: Interleukin-10: Effects on phagocytosis and adhesion molecule expression of granulocytes and monocytes in a comparison with prednisolone. Eur J Med Res 4: 85-94, 1999.

30. de Waal Malefyt R, Abrams J, Bennett B, Figdor CG and de Vries JE: Interleukin 10 (IL-10) inhibits cytokine synthesis by human monocytes: An autoregulatory role of IL-10 produced by monocytes. J Exp Med 174: 1209-1220, 1991.

31. Fiorentino DF, Zlotnik A, Mosmann TR, Howard M and O'Garra A: IL-10 inhibits cytokine production by activated-macrophages. J Immunol 147: 3815-3822, 1991.

32. Häcker H, Redecke V, Blagoev B, Kratchmarova I, Hsu LC, Wang GG, Kamps MP, Raz E, Wagner H, Häcker G, et al: Specificity in Toll-like receptor signalling through distinct effector functions of TRAF3 and TRAF6. Nature 439: 204-207, 2006.

33. Steinbrink K, Wölfl M, Jonuleit H, Knop J and Enk AH: Induction of tolerance by IL-10-treated dendritic cells. J Immunol 159: 4772-4780, 1997.

34. Steinbrink K, Jonuleit H, Müller G, Schuler G, Knop J and Enk AHL: Interleukin-10-treated human dendritic cells induce a melanoma-antigen-specific anergy in CD8(+) T cells resulting in a failure to lyse tumor cells. Blood 93: 1634-1642, 1999.

35. Vannucci L, Lai M, Chiuppesi F, Ceccherini-Nelli L and Pistello M: Viral vectors: A look back and ahead on gene transfer technology. New Microbiol 36: 1-22, 2013.

36. Leibowitz G, Beattie GM, Kafri T, Cirulli V, Lopez AD, Hayek A and Levine F: Gene transfer to human pancreatic endocrine cells using viral vectors. Diabetes 48: 745-753, 1999.

37. Csete ME, Benhamou PY, Drazan KE, Wu L, McIntee DF, Afra R, Mullen Y, Busuttil RW and Shaked A: Efficient gene transfer to pancreatic islets mediated by adenoviral vectors. Transplantation 59: 263-268, 1995.

38. Fiorentino DF, Bond MW and Mosmann TR: Two types of mouse T helper cell. IV. Th2 clones secrete a factor that inhibits cytokine production by Th1 clones. J Exp Med 170: 2081-2095, 1989.
39. Eisenbarth GS: Type I diabetes mellitus. A chronic autoimmune disease. N Engl J Med 314: 1360-1368, 1986.

40. Csorba TR, Lyon AW and Hollenberg MD: Autoimmunity and the pathogenesis of type 1 diabetes. Crit Rev Clin Lab Sci 47: $51-71,2010$.

41. Lu Y, Ponton A, Okamoto H, Takasawa S, Herrera PL and Liu JL: Activation of the Reg family genes by pancreatic-specific IGF-I gene deficiency and after streptozotocin-induced diabetes in mouse pancreas. Am J Physiol Endocrinol Metab 291: E50-E58, 2006.

42. Moore F, Naamane N, Colli ML, Bouckenooghe T, Ortis F, Gurzov EN, Igoillo-Esteve $\mathrm{M}$, Mathieu C, Bontempi G, Thykjaer T, et al: STAT1 is a master regulator of pancreatic \{beta\}-cell apoptosis and islet inflammation. J Biol Chem 286: 929-941, 2011.

43. Savinov AY, Wong FS and Chervonsky AV: IFN-gamma affects homing of diabetogenic T cells. J Immunol 167: 6637-6643, 2001.

44. Rapoport MJ, Jaramillo A, Zipris D, Lazarus AH, Serreze DV, Leiter EH, Cyopick P, Danska JS and Delovitch TL: Interleukin 4 reverses $\mathrm{T}$ cell proliferative unresponsiveness and prevents the onset of diabetes in nonobese diabetic mice. J Exp Med 178: 87-99, 1993.

45. Mueller R, Krahl T and Sarvetnick N: Pancreatic expression of interleukin-4 abrogates insulitis and autoimmune diabetes in nonobese diabetic (NOD) mice. J Exp Med 184: 1093-1099, 1996.

46. Gallichan WS, Balasa B, Davies JD and Sarvetnick N: Pancreatic IL-4 expression results in islet-reactive Th2 cells that inhibit diabetogenic lymphocytes in the nonobese diabetic mouse. J Immunol 163: 1696-1703, 1999.

47. Berman MA, Sandborg CI, Wang Z, Imfeld KL, Zaldivar F Jr, Dadufalza V and Buckingham BA: Decreased IL-4 production in new onset type I insulin-dependent diabetes mellitus. J Immunol 157: 4690-4696, 1996.

48. Rehman KK, Trucco M, Wang Z, Xiao X and Robbins PD: AAV8-mediated gene transfer of interleukin-4 to endogenous beta-cells prevents the onset of diabetes in NOD mice. Mol Ther 16: 1409-1416, 2008.

49. Ludvigsson J: C-peptide in diabetes diagnosis and therapy. Front Biosci (Elite Ed) 5: 214-223, 2013

50. Hills CE and Brunskill NJ: Cellular and physiological effects of C-peptide. Clin Sci (Lond) 116: 565-574, 2009.

51. Hills CE, Brunskill NJ and Squires PE: C-peptide as a therapeutic tool in diabetic nephropathy. Am J Nephrol 31: 389-397, 2010.

52. Johansson BL, Kernell A, Sjöberg S and Wahren J: Influence of combined C-peptide and insulin administration on renal function and metabolic control in diabetes type 1. J Clin Endocrinol Metab 77: 976-981, 1993.

53. Ekberg K, Brismar T, Johansson BL, Jonsson B, Lindström P and Wahren J: Amelioration of sensory nerve dysfunction by C-Peptide in patients with type 1 diabetes. Diabetes 52: 536-541, 2003.

54. Cotter MA, Ekberg K, Wahren J and Cameron NE: Effects of proinsulin C-peptide in experimental diabetic neuropathy: Vascular actions and modulation by nitric oxide synthase inhibition. Diabetes 52: 1812-1817, 2003.

55. Manzella D, Ragno E, Abbatecola AM, Grella R and Paolisso G: Residual C-peptide secretion and endothelial function in patients with Type II diabetes. Clin Sci (Lond) 105: 113-118, 2003. 